\title{
The role of ecological strategies in the colonization success of pelagic fish in a large tropical reservoir (Petit-Saut Reservoir, French Guiana)
}

\author{
Bernard DE MÉRONA ${ }^{1, a}$ and Régis VIGOUROUX ${ }^{2}$ \\ 1 UMR Borea, centre IRD de Cayenne, rte de Montabo km 0.275, BP 165, 97323-Cayenne Cedex, France, \\ French Guiana \\ 2 Laboratoire Hydreco, BP 823, 97388 Kourou Cedex, France, French Guiana
}

Received 6 December 2010; Accepted 19 December 2011

\begin{abstract}
Although many studies have been made on fish community changes in reservoirs, the diversity of situations means that general models are still difficult to construct. In order to be useful to managers, the information gathered in these studies must cover the regional taxonomic peculiarities. The inclusion of ecological strategies allows the detection of general patterns of fish community change. In the present study, multivariate analyses and non-parametric tests were used in order to detect relationships between ecological traits of 39 fish species and pelagic fish assemblages. We used gillnet captures of fish made in the Sinnamary River before filling of the Petit-Saut Reservoir and in the reservoir 8 years after closure of the dam and published data on fish species diet, life history parameters and morphology. Significant relationships were detected between fish assemblages and every ecological trait, which would have allowed the forecast of the type of species able to colonize the Petit-Saut Reservoir. Provided that the general characteristics of a river before damming are taken into account, it seems that feeding strategies can be used to predict future fish population and species changes on a general basis. Conversely, the lack of published data prevents definitive conclusions from being drawn concerning life-history and swimming strategies.
\end{abstract}

Key words: Freshwater fish / Biodiversity conservation / Life history / Diet / Ecomorphology / South America

\section{Introduction}

As early as the 1950s, studies were conducted on changes in the fish communities of tropical reservoirs, generating numerous data (Lelek and El Zarka 1973; Ita 1984; Vanderpuye 1984; Santos and Mérona 1996; Agostinho et al. 1999; Agostinho et al. 2007; Mol et al. 2007). However, to make general models of changes in fish assemblages in reservoirs, it is necessary to make comparative studies between different ecological situations, which is still difficult. First, the fish fauna that initially colonizes a reservoir is directly dependent on the fish fauna present in the river before damming. A detailed knowledge of the pre-existing fish assemblages in a river that is to be dammed is essential in order to understand the colonization dynamics of the assemblages in the new reservoir (Agostinho et al. 1999). Second, since different biogeographic areas are being addressed, comparisons cannot be made from lists of

\footnotetext{
a Corresponding author: bernard.de.merona@ird.fr
}

species but are only possible based on general criteria. Following the "habitat templet concept" (Southwood 1977), the habitat constitutes a templet of spatio-temporal variability in which evolution moulds characteristic life-history traits. This concept has since been applied to rivers (Townsend and Hildrew 1994; Townsend et al. 1997), leading to the hypothesis that, for a given taxonomic group, the distribution of traits is predictable from the spatio-temporal variability of the environment. A similar approach was developed by Winemiller (1989), who stated that life-history strategies of fish species depend on the variability and the predictability of the environment (Winemiller 1989; Winemiller and Rose 1992). These approaches offer the possibility of using combinations of the ecological traits expressed in the assemblage to assess the impacts of human-induced disturbances. The use of a functional measure (diversity of ecological traits) instead of a taxonomic one (list of taxa) provides a better indication of the change occurring in the system (Hoeinghaus et al. 2007). Moreover, this approach permits the establishment of general models of community response to disturbances, independent of their specific composition 


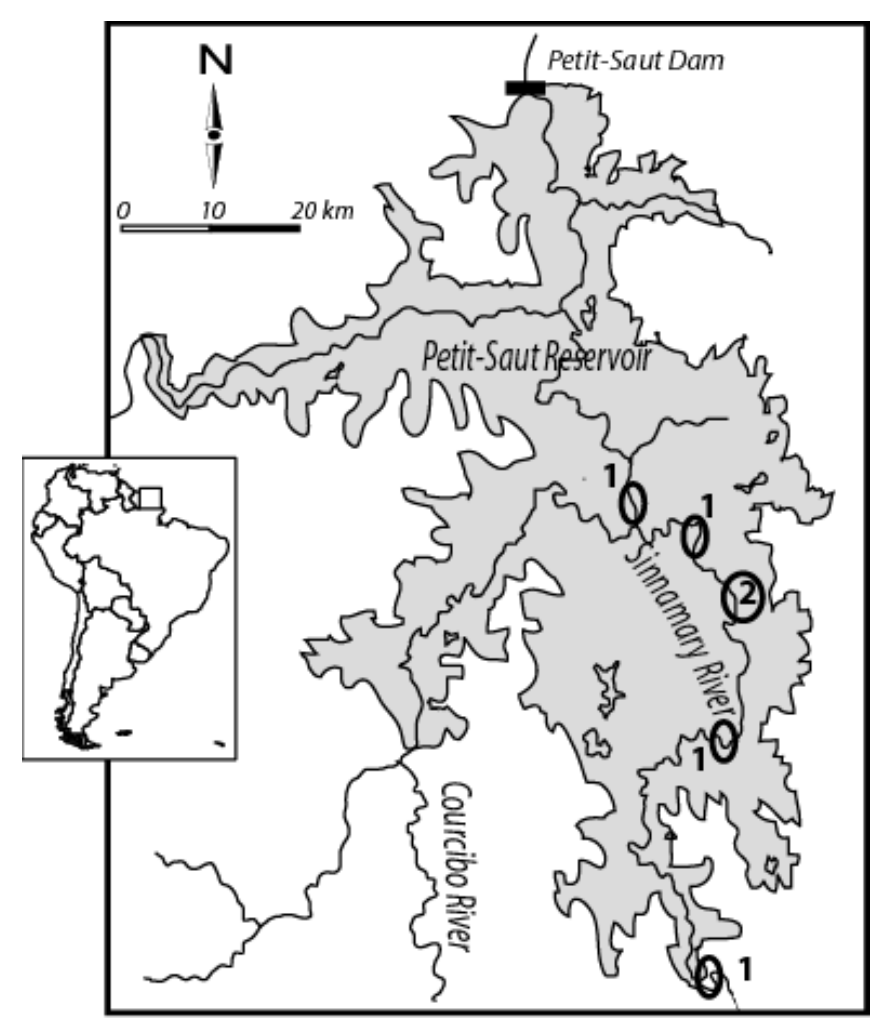

Fig. 1. Study site. Open ellipses indicate the area of sampling. (1) in the river before filling; (2) in the reservoir.

(Charvet et al. 2000). An example of this approach is the development of the Index of Biotic Integrity (IBI) (Karr 1981), which is based on various functional descriptors (feeding or habitat use) that supposedly react to perturbations in a predictable manner. The implantation of a reservoir on a river constitutes a major perturbation for fish. The aquatic habitat is deeply, rapidly and permanently modified, so it can be hypothesized that the physico-chemical characteristics of the reservoir will limit the potential for riverine species to develop populations. In other words, reservoirs can be compared to environmental filters which, from the pool of species present in the river, will retain those unable to find their ecological requirements in the newly formed lake (Tonn et al. 1990).

Based on these concepts and hypotheses, the present work aimed to (1) illustrate the changes in species composition and relative abundance of species in the pelagic fish assemblages in a tropical reservoir 10 years after its filling and (2) identify the ecological traits that contribute to these changes and hence determine the final composition of the reservoir assemblages. Three kinds of traits were analysed, related to feeding habits, life-history strategies and body morphology.

\section{Material and methods}

\subsection{Study site}

The Sinnamary River, located in the centre of French Guiana, is approximately $260 \mathrm{~km}$ long and drains an area of

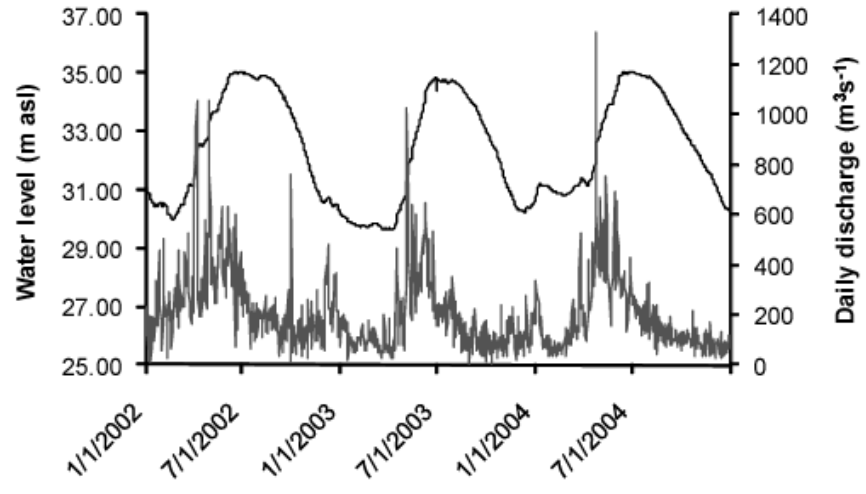

Fig. 2. Daily variations of discharge into the Sinnamary River and water level in the Petit-Saut Reservoir between January 2002 and December 2004.

$6565 \mathrm{~km}^{2}$ (Fig. 1). The basin receives a mean annual precipitation of $3000 \mathrm{~mm}$. The mean annual discharge before damming was $262 \mathrm{~m}^{3} \mathrm{~s}^{-1}$ (Sissakian 1997), with a hydrograph showing large seasonal and stochastic variations (Fig. 2). In January 1994, a dam was closed in the downstream section of the river at about $60 \mathrm{~km}$ from its mouth in the Petit-Saut area. The damming led to the formation of a large reservoir of more than $300 \mathrm{~km}^{2}$. Subsequent water level fluctuations in the reservoir were large and seasonally predictable (Fig. 2).

\subsection{Sampling}

Fish were sampled using one to five sets of 10 surface gillnets of $25 \times 2 \mathrm{~m}$, with mesh sizes of 10, 15, 20, 25, 30, 35, 40, 50, 60 and $70 \mathrm{~mm}$ between adjacent knots. The nets were set at sunset and retrieved the next morning. This procedure was adopted after checking that daytime captures did not bring any further significant information about composition and structure of fish assemblages (Mérona and Albert 1999). Fifteen samples were taken in the river during the period of reservoir filling from June 1994 to December 1995. These samples were taken each month, except in July and September 1994 and August and October 1995, in the area consisting of pools of relatively still water situated above the riffle immediately upstream from the progression of water in the reservoir. Nets were placed in areas with only a small current or none at all. The central part of the reservoir was sampled every two months between March 2002 and July 2003 and in November 2003 (10 samples). Here, the nets were placed in open water at a growing distance from the bank and attached to the dead trees remaining in the lake (Fig. 1). Fish captures were expressed in number of specimens per species per unit of effort (one set of nets during one night).

The captured fish were identified to species level using recent taxonomic reviews (Planquette et al. 1996; Keith et al. 2000; Le Bail et al. 2000). A list of the most abundant species classified by family is given in Table 1. Every specimen was measured (standard length, to the nearest $\mathrm{mm}$ ) and weighed (to the nearest $\mathrm{g}$ ). 
Table 1. List of the most abundant species captured in the Sinnamary River and Petit-Saut Reservoir, classified by family and genus.

\begin{tabular}{|c|c|c|}
\hline Family & Species and Authority & $\begin{array}{l}\text { Fish } \\
\text { Code }\end{array}$ \\
\hline \multirow[t]{2}{*}{ Acestrorhynchidae } & Acestrorhynchus falcatus (Bloch, 1794) & Afal \\
\hline & Acestrorhynchus microlepis (Schomburgk, 1841) & Amic \\
\hline \multirow[t]{6}{*}{ Anostomidae } & Anostomus brevior Géry, 1960 & Abre \\
\hline & Leporinus fasciatus (Bloch, 1794) & Lfas \\
\hline & Leporinus friderici (Bloch, 1794) & Lfri \\
\hline & Leporinus gossei Géry, Planquette \& Le Bail, 1991 & Lgos \\
\hline & Leporinus granti Eigenmann, 1912 & Lgra \\
\hline & Leporinus maculatus Müller \& Troschel, 1844 & Lmac \\
\hline \multirow[t]{3}{*}{ Auchenipteridae } & Auchenipterus nuchalis (Spix, 1829) & Anuc \\
\hline & Parauchenipterus galeatus (Linné, 1766) & Pgal \\
\hline & Tatia intermedia (Steindachner, 1876) & Tint \\
\hline Callichthyidae & Megalechis thoracata (Valenciennes, 1840) & Mtho \\
\hline \multirow[t]{17}{*}{ Characidae } & Astyanax bimaculatus (Linné, 1758) & Abim \\
\hline & Bryconops affinis (Günther, 1864) & Baff \\
\hline & Bryconops melanurus (Bloch, 1795) & Bmel \\
\hline & Byconops caudomaculatus (Günther, 1869) & Bcau \\
\hline & Charax pauciradiatus Günther, 1864 & Cpau \\
\hline & Cyphocharax sp. & Cyp1 \\
\hline & Jubiaba keithi (Géry, Planquette \& Le Bail, 1996) & Jmeu \\
\hline & Jubiaba meunieri (Géry, Planquette \& Le Bail, 1996) & Czun \\
\hline & Moenkhausia chrysargyrea (Günther, 1864) & Mchr \\
\hline & Moenkhausia georgiae Géry, 1966 & Mgeo \\
\hline & Moenkhausia hemigrammoides Géry, 1966 & Mhem \\
\hline & Moenkhausia oligolepis (Günther, 1864) & Moli \\
\hline & Moenkhausia surinamensis Géry, 1965 & Msur \\
\hline & Myleus rhomboidalis (Cuvier, 1818) & Mrho \\
\hline & Myleus ternetzi (Norman, 1929) & Mter \\
\hline & Poptella brevispina Reis, 1989 & Pbre \\
\hline & Triportheus rotundatus (Schomburk, 1841) & Trot \\
\hline Chilodontidae & Chilodus zunevei Puyo, 1945 & Jkei \\
\hline \multirow[t]{5}{*}{ Cichlidae } & Cichlasoma bimaculatum (Linné, 1758) & Cbim \\
\hline & Crenicichla saxatilis (Linné, 1758) & Csax \\
\hline & Geophagus surinamensis (Bloch, 1791) & Gsur \\
\hline & Krobia guianensis Regan, 1905 & Kgui \\
\hline & Satanoperca jurupari Heckel, 1840 & Sjur \\
\hline Crenuchidae & Characidium sp. & Chsp \\
\hline \multirow[t]{3}{*}{ Curimatidae } & Curimata cyprinoides (Linné, 1758) & Cсур \\
\hline & Cyphocharax helleri (Steindachner, 1910) & Chel \\
\hline & Cyphocharax spilurus (Günther, 1864) & Cysp \\
\hline Doradidae & Doras carinatus (Linné, 1766) & Dcar \\
\hline \multirow[t]{3}{*}{ Erythrinidae } & Hoplerythrinus unitaeniatus (Spix, 1829) & Houn \\
\hline & Hoplias aimara (Valenciennes, 1840) & Haim \\
\hline & Hoplias malabaricus (Bloch, 1794) & Hmal \\
\hline \multirow[t]{3}{*}{ Hemiodontidae } & Bivibranchia bimaculata Vari, 1985 & Bbim \\
\hline & Hemiodopsis quadrimaculatus (Pellegrin, 1908) & Hqua \\
\hline & Hemiodus unimaculatus (Bloch, 1794) & Heun \\
\hline
\end{tabular}


Table 1. Continued.

\begin{tabular}{|c|c|c|}
\hline Family & Species and Authority & $\begin{array}{l}\text { Fish } \\
\text { Code }\end{array}$ \\
\hline Hypopomidae & Hypopomus artedi (Kaup, 1856) & Hart \\
\hline \multirow[t]{6}{*}{ Loricariidae } & Ancistrus hoplogenys (Günther, 1864) & Ahop \\
\hline & Cteniloricaria maculata (Boeseman, 1971) & $\mathrm{Cmac}$ \\
\hline & Harttia surinamensis Boeseman, 1971 & Hsur \\
\hline & Hypostomus gymnorhynchus (Norman, 1926) & Hgym \\
\hline & Lithoxus plaquettei Boeseman, 1982 & Lpla \\
\hline & Loricaria cataphracta Linné, 1758 & Lcat \\
\hline \multirow[t]{4}{*}{ Pimelodidae } & Pimelodella cristata (Müller \& Troschel, 1848) & Pcri \\
\hline & Pimelodella geryi (Hoedeman, 1961) & Pger \\
\hline & Pimelodus ornatus Kner, 1858 & Porn \\
\hline & Rhambdia quelen (Quoy \& Gaimard, 1824) & Rque \\
\hline Polycentridae & Polycentrus punctatus (Linné, 1758) & Ppun \\
\hline Sciaenidae & Plagioscion squamosissimus (Heckel, 1840) & Psqu \\
\hline \multirow[t]{2}{*}{ Sternopygidae } & Eigenmania virescens (Valenciennes, 1847) & Evir \\
\hline & Sternopygus macrurus (Bloch et Schneider, 1801) & Smac \\
\hline
\end{tabular}

\subsection{Ecological traits}

Ecological traits of the species were obtained from specimens captured in the river during the pre-closure period, or upstream from the reservoir after closure. Species diet and feeding guilds were obtained either from Mérona et al. (2003) or from original data (Table 2). The food items identified in the fish stomachs were: organic benthic layer or detritus (Det), fragments of higher plants (Vege), algae (Alg), chaoborid larvae (Chao), decapodes (Dec), other aquatic invertebrates (Aqu Inv), terrestrial invertebrates (Terr Inv) and fish (Fish). Due to their poor representation in the stomach contents examined, the categories chaoborid larvae, decapodes and algae were grouped with categories Aqu. Inv, Fish and Vege, respectively, for the statistical analyses.

The method for stomach content analysis was derived from the point method: the relative volume of each food item to the entire content of the stomach was estimated under stereomicroscope and expressed as a percentage. Feeding niche breadths were calculated using Levin's standardized index:

$$
B_{i}=\left[\left(\sum_{j} P_{i j}^{2}\right)^{-1}-1\right](n-1)^{-1},
$$

where $P_{i j}$ is the proportion of prey $j$ in the diet of species $i$ and $n$ the number of prey categories (Hurlbert 1978). Feeding niche breadth was included in the feeding traits because it constitutes an efficient index of omnivory.

Life-history traits were taken from Ponton and Mérona (1998; Appendix 1). They included: maximum standard length (MSL), length of the reproductive period in months (LRP), relative length at first maturity for females (L1R), absolute fecundity (FEC), relative fecundity (RFE), percentage of mature oocytes in the ovary (MO) and mean diameter of mature oocytes (MDO). These life-history traits were the ones identified by Winemiller $(1989,1992)$ as determinant in describing life-history strategies of fish species.

Morphological measurements were taken on 1 to 7 individual fish (Appendix 2). Variables considered were adapted from Gatz (1979a) and were assumed to be related to locomotion capacity:

- Relative head length (the measure taken from the extremity of the head to the posterior border of the opercule divided by the standard length: RHL);

- flatness index (the maximum body depth divided by the maximum body width: FI);

- relative body depth (the maximum body depth divided by the standard length: RBD);

- relative caudal peduncle length (the measure taken from a vertical through the posterior border of the anal fin to the end of vertebral column divided by the standard length: RPDL);

- caudal peduncle flatness (the peduncle depth divided by the maximum peduncle width: PDLF);

- relative caudal area (caudal area measured by a planimeter divided by half the product of standard length and maximum body depth: RCAA);

- relative pectoral length (the maximum length of the pectoral divided by the standard length: RPCL);

- relative pectoral area (pectoral area measured by a planimeter divided by half the product of standard length and maximum body depth: RPCA);

- eye position (the proportion of head depth below the centre of the eye: EP). 
Table 2. Diet composition, niche breadth and feeding guild of 39 fish species in the Sinnamary River, expressed in volumetric percentage of 7 food categories. Nb: Number of fish, Det: organic benthic layer or detritus, Vege: fragments of higher plants, Alg: algae, Chao: chaoborid larvae (Diptera), Dec: decapodes, Aqu. Inv: other aquatic invertebrates, Terr. Inv: Terrestrial invertebrates, Fish: fish. List of species codes in Table 1.

\begin{tabular}{|c|c|c|c|c|c|c|c|c|c|c|c|}
\hline \multirow{2}{*}{$\begin{array}{l}\text { Species } \\
\text { Code }\end{array}$} & \multirow[b]{2}{*}{$\mathrm{Nb}$} & \multicolumn{8}{|c|}{ Diet (food categories in volumetric percentage, \%) } & \multirow{2}{*}{$\begin{array}{l}\text { Feeding } \\
\text { niche } \\
\text { breadth }\end{array}$} & \multirow{2}{*}{$\begin{array}{l}\text { Feeding } \\
\text { guild }\end{array}$} \\
\hline & & Det & Vege & Alg & Chao & Dec & Aqu. Inv & Terr. Inv & Fish & & \\
\hline$\overline{\text { Abim }}$ & 5 & - & 30.00 & - & - & - & - & 70.00 & - & 0.104 & invertivore \\
\hline Abre & 2 & 100.00 & - & - & - & - & - & - & - & 0 & detritivore \\
\hline Afal & 32 & - & - & - & - & - & - & - & 100.00 & 0 & piscivore \\
\hline Amic & 22 & - & - & - & - & - & - & - & 100.00 & 0 & piscivore \\
\hline Anuc & 147 & - & 10.54 & - & 3.17 & - & 4.12 & 81.61 & 0.54 & 0.067 & invertivore \\
\hline Baff & 60 & - & 5.17 & - & - & - & 4.22 & 90.61 & - & 0.030 & invertivore \\
\hline Bcau & 118 & 0.34 & 21.80 & - & - & - & 0.75 & 76.26 & 0.85 & 0.084 & invertivore \\
\hline Bmel & 136 & 2.06 & 29.74 & - & 0.49 & - & 1.48 & 66.24 & - & 0.128 & omnivore \\
\hline Cbim & 3 & - & - & - & - & 50.00 & 50.00 & - & - & 0.143 & omnivore \\
\hline Ccyp & 16 & 100.00 & - & - & - & - & - & - & - & 0 & detritivore \\
\hline Chel & 2 & 50.00 & 50.00 & - & - & - & - & - & - & 0.143 & herbivore \\
\hline Cpau & 13 & - & - & - & - & 15.38 & - & 7.69 & 76.92 & 0.087 & piscivore \\
\hline Cyp1 & 14 & 74.29 & - & - & - & - & 4.29 & - & - & 0.116 & detritivore \\
\hline Cysp & 21 & 71.43 & 23.81 & - & - & - & - & - & 4.76 & 0.108 & detritivore \\
\hline Czun & 20 & 97.00 & - & - & - & - & 2.00 & 1.00 & - & 0.009 & detritivore \\
\hline Evir & 7 & 14.29 & - & - & - & - & 15.71 & 70.00 & - & 0.124 & invertivore \\
\hline Gsur & 3 & 33.33 & - & - & - & - & 33.33 & 33.33 & - & 0.286 & omnivore \\
\hline Haim & 10 & - & - & - & - & 10.00 & - & - & 90.00 & 0.031 & piscivore \\
\hline Heun & 12 & 98.33 & 1.67 & - & - & - & - & - & - & 0.050 & detritivore \\
\hline Hgym & 3 & 100.00 & - & - & - & - & - & - & - & 0 & detritivore \\
\hline Hmal & 1 & - & - & - & - & - & - & - & 100.00 & 0 & piscivore \\
\hline Houn & 2 & - & - & - & - & - & - & - & 100.00 & 0 & piscivore \\
\hline Hqua & 35 & 48.00 & 28.57 & 19.43 & - & - & 1.14 & - & - & 0.265 & herbivore \\
\hline Jkei & 12 & - & 43.33 & - & - & - & - & 48.33 & 8.33 & 0.191 & omnivore \\
\hline Jmeu & 5 & - & 100.00 & - & - & - & - & - & - & 0 & herbivore \\
\hline Lfas & 4 & 25.00 & 50.00 & - & - & - & - & 25.00 & - & 0.239 & herbivore \\
\hline Lfri & 139 & 5.47 & 75.18 & 0.29 & - & 0.14 & 1.37 & 8.59 & 8.53 & 0.102 & herbivore \\
\hline Lgos & 2 & 30.00 & 50.00 & - & - & - & 20.00 & - & - & 0.233 & herbivore \\
\hline Lgra & 14 & 10.71 & 60.71 & - & - & - & - & 21.43 & 7.14 & 0.189 & herbivore \\
\hline Mgeo & 32 & 3.75 & 46.56 & - & - & - & 1.46 & 47.60 & 0.63 & 0.178 & omnivore \\
\hline Moli & 33 & 3.03 & 35.66 & - & - & - & - & 61.31 & - & 0.141 & omnivore \\
\hline Mrho & 6 & - & 96.67 & - & - & - & 3.33 & - & - & 0.010 & herbivore \\
\hline Msur & 64 & 3.44 & 62.32 & 0.94 & - & - & 0.31 & 32.99 & - & 0.144 & omnivore \\
\hline Mter & 145 & 0.97 & 97.40 & - & - & - & 0.19 & 1.45 & - & 0.008 & herbivore \\
\hline Pbre & 112 & 1.46 & 35.25 & - & - & 0.08 & 0.89 & 60.80 & 1.52 & 0.146 & omnivore \\
\hline Pgal & 5 & - & 5.00 & - & - & 10.00 & - & 65.00 & 20.00 & 0.158 & omnivore \\
\hline Psqu & 5 & - & - & - & - & - & - & - & 100.00 & 0 & piscivore \\
\hline Sjur & 4 & - & 25.00 & 25.00 & - & - & 50.00 & - & - & 0.238 & omnivore \\
\hline Trot & 201 & 0.76 & 63.81 & 0.30 & - & 0.14 & 1.08 & 30.34 & 3.57 & 0.142 & omnivore \\
\hline
\end{tabular}

\subsection{Data analysis}

Captures were expressed in numbers of each species per set of 10 nets during one night. In order to exclude the weight of very rare species, we excluded species representing less than 0.1 per cent of the river or reservoir samples from the statistical analyses.
A correspondence analysis (COA) was done on the species $\times$ samples matrix in order to visualize the distribution of samples according to their position in the river or reservoir, and the associated species.

Three kinds of ecological strategies were considered: feeding strategies, reproductive strategies and locomotion strategies. 
Table 3. Capture per unit effort (1 set of gillnets during one night) of fish species in the Sinnamary River in 1994-1995 and in the Petit-Saut reservoir in 2002-2003. Species are ordered by decreasing abundance in the river. Percentages are given between brackets.

\begin{tabular}{|c|c|c|c|}
\hline Species and Authority & $\begin{array}{c}\text { Species } \\
\text { Code }\end{array}$ & Total River & Total Reservoir \\
\hline Auchenipterus nuchalis (Spix, 1829) & Anuc & $140.0(21.47)$ & $12.4(5.50)$ \\
\hline Byconops caudomaculatus (Günther, 1869) & Bcau & $137.9(21.14)$ & $18.1(8.05)$ \\
\hline Acestrorhynchus falcatus (Bloch, 1794) & Afal & $61.9(9.49)$ & - \\
\hline Cyphocharax spilurus (Günther, 1864) & Cysp & $50.5(7.74)$ & $2.1(0.92)$ \\
\hline Triportheus rotundatus (Schomburk, 1841) & Trot & $43.4(6.66)$ & $79.9(35.53)$ \\
\hline Poptella brevispina Reis, 1989 & Pbre & $41.3(6.34)$ & $6.9(3.07)$ \\
\hline Leporinus friderici (Bloch, 1794) & Lfri & $28.4(4.35)$ & $5.8(2.60)$ \\
\hline Charax pauciradiatus Günther, 1864 & Cpau & $25.5(3.91)$ & $15.7(6.99)$ \\
\hline Acestrorhynchus microlepis (Schomburgk, 1841) & Amic & $22.7(3.48)$ & $9.2(4.11)$ \\
\hline Hemiodopsis quadrimaculatus (Pellegrin, 1908) & Hqua & $17.6(2.70)$ & $14.6(6.51)$ \\
\hline Bryconops affinis (Günther, 1864) & Baff & $13.0(1.99)$ & $4.2(1.88)$ \\
\hline Bryconops melanurus (Bloch, 1795) & Bmel & $12.8(1.96)$ & $1.3(0.58)$ \\
\hline Curimata cyprinoides (Linné, 1758) & Ccyp & $12.2(1.87)$ & $28.4(12.63)$ \\
\hline Astyanax bimaculatus (Linné, 1758) & Abim & $6.2(0.95)$ & $0.2(0.08)$ \\
\hline Myleus ternetzi (Norman, 1929) & Mter & $5.9(0.90)$ & $0.7(0.31)$ \\
\hline Cyphocharax sp. & Cyp1 & $5.0(0.77)$ & $1.8(0.80)$ \\
\hline Hemiodus unimaculatus (Bloch, 1794) & Heun & $4.9(0.75)$ & $10.3(4.56)$ \\
\hline Moenkhausia oligolepis (Günther, 1864) & Moli & $4.0(0.61)$ & $<0.1(0.01)$ \\
\hline Chilodus zunevei Puyo, 1945 & Jkei & $2.5(0.38)$ & $0.1(0.04)$ \\
\hline Moenkhausia surinamensis Géry, 1965 & Msur & $2.0(0.30)$ & $0.5(0.24)$ \\
\hline Cyphocharax helleri (Steindachner, 1910) & Chel & $1.9(0.29)$ & - \\
\hline Moenkhausia georgiae Géry, 1966 & Mgeo & $1.4(0.21)$ & $0.5(0.22)$ \\
\hline Leporinus granti Eigenmann, 1912 & Lgra & $1.4(0.21)$ & $0.2(0.10)$ \\
\hline Jubiaba keithi (Géry, Planquette \& Le Bail, 1996) & Jmeu & $1.3(0.20)$ & $0.6(0.26)$ \\
\hline Hypostomus gymnorhynchus (Norman, 1926) & Hgym & $1.2(0.18)$ & $1.6(0.72)$ \\
\hline Anostomus brevior Géry, 1960 & Abre & $0.9(0.13)$ & - \\
\hline Leporinus fasciatus (Bloch, 1794) & Lfas & $0.8(0.13)$ & $2.3(1.00)$ \\
\hline Hoplias aimara (Valenciennes, 1840) & Haim & $0.7(0.11)$ & $0.3(0.12)$ \\
\hline Hoplerythrinus unitaeniatus (Spix, 1829) & Houn & $0.7(0.11)$ & - \\
\hline Parauchenipterus galeatus (Linné, 1766) & Pgal & $0.5(0.08)$ & $1.3(0.60)$ \\
\hline Hoplias malabaricus (Bloch, 1794) & Hmal & $0.5(0.08)$ & $<0.1(0.01)$ \\
\hline Moenkhausia chrysargyrea (Günther, 1864) & Mchr & $0.5(0.07)$ & - \\
\hline Leporinus gossei Géry, Planquette \& Le Bail, 1991 & Lgos & $0.4(0.06)$ & $0.2(0.07)$ \\
\hline Jubiaba meunieri (Géry, Planquette \& Le Bail, 1996) & Czun & $0.3(0.05)$ & $1.0(0.44)$ \\
\hline Eigenmania virescens (Valenciennes, 1847) & Evir & $0.3(0.05)$ & $0.4(0.18)$ \\
\hline Myleus rhomboidalis (Cuvier, 1818) & Mrho & $0.2(0.04)$ & $0.3(0.12)$ \\
\hline Pimelodus ornatus Kner, 1858 & Porn & $0.2(0.03)$ & $<0.1(0.01)$ \\
\hline Leporinus maculatus Müller \& Troschel, 1844 & Lmac & $0.1(0.02)$ & $0.1(0.03)$ \\
\hline Ancistrus hoplogenys (Günther, 1864) & Ahop & $0.1(0.02)$ & - \\
\hline Bivibranchia bimaculata Vari, 1985 & Bbim & $0.1(0.02)$ & - \\
\hline Harttia surinamensis Boeseman, 1971 & Hsur & $0.1(0.02)$ & - \\
\hline Pimelodella cristata (Müller \& Troschel, 1848) & Pcri & $0.1(0.02)$ & - \\
\hline Satanoperca jurupari Heckel, 1840 & Sjur & $0.1(0.01)$ & $0.3(0.12)$ \\
\hline Characidium sp. & Chsp & $0.1(0.01)$ & - \\
\hline Loricaria cataphracta Linné, 1758 & Lcat & $0.1(0.01)$ & - \\
\hline Moenkhausia hemigrammoides Géry, 1966 & Mhem & $0.1(0.01)$ & - \\
\hline Megalechis thoracata (Valenciennes, 1840) & Mtho & $0.1(0.01)$ & - \\
\hline Pimelodella geryi (Hoedeman, 1961) & Pger & $0.1(0.01)$ & - \\
\hline Tatia intermedia (Steindachner, 1876) & Tint & $0.1(0.01)$ & - \\
\hline Geophagus surinamensis (Bloch, 1791) & Gsur & $<0.1(0.01)$ & $0.3(0.15)$ \\
\hline Sternopygus macrurus (Bloch et Schneider, 1801) & Smac & $<0.1(0.01)$ & $<0.1(0.01)$ \\
\hline Cteniloricaria maculata (Boeseman, 1971) & $\mathrm{Cmac}$ & $<0.1(0.01)$ & - \\
\hline Lithoxus plaquettei Boeseman, 1982 & Lpla & $<0.1(0.01)$ & - \\
\hline Hypopomus artedi (Kaup, 1856) & Hart & $<0.1(0.01)$ & - \\
\hline Polycentrus punctatus (Linné, 1758) & Ppun & $<0.1(0.01)$ & - \\
\hline Rhambdia quelen (Quoy \& Gaimard, 1824) & Rque & $<0.1(0.01)$ & - \\
\hline Plagioscion squamosissimus (Heckel, 1840) & Psqu & - & $2.2(0.99)$ \\
\hline Cichlasoma bimaculatum (Linné, 1758) & Cbim & - & $0.7(0.29)$ \\
\hline Crenicichla saxatilis (Linné, 1758) & Csax & - & $0.2(0.07)$ \\
\hline Doras carinatus (Linné, 1766) & Dcar & - & $0.1(0.06)$ \\
\hline Krobia guianensis Regan, 1905 & Kgui & - & $<0.1(0.01)$ \\
\hline Mean CPUE & & 652.1 & 225.0 \\
\hline Number of species & & 54.0 & 39.0 \\
\hline
\end{tabular}



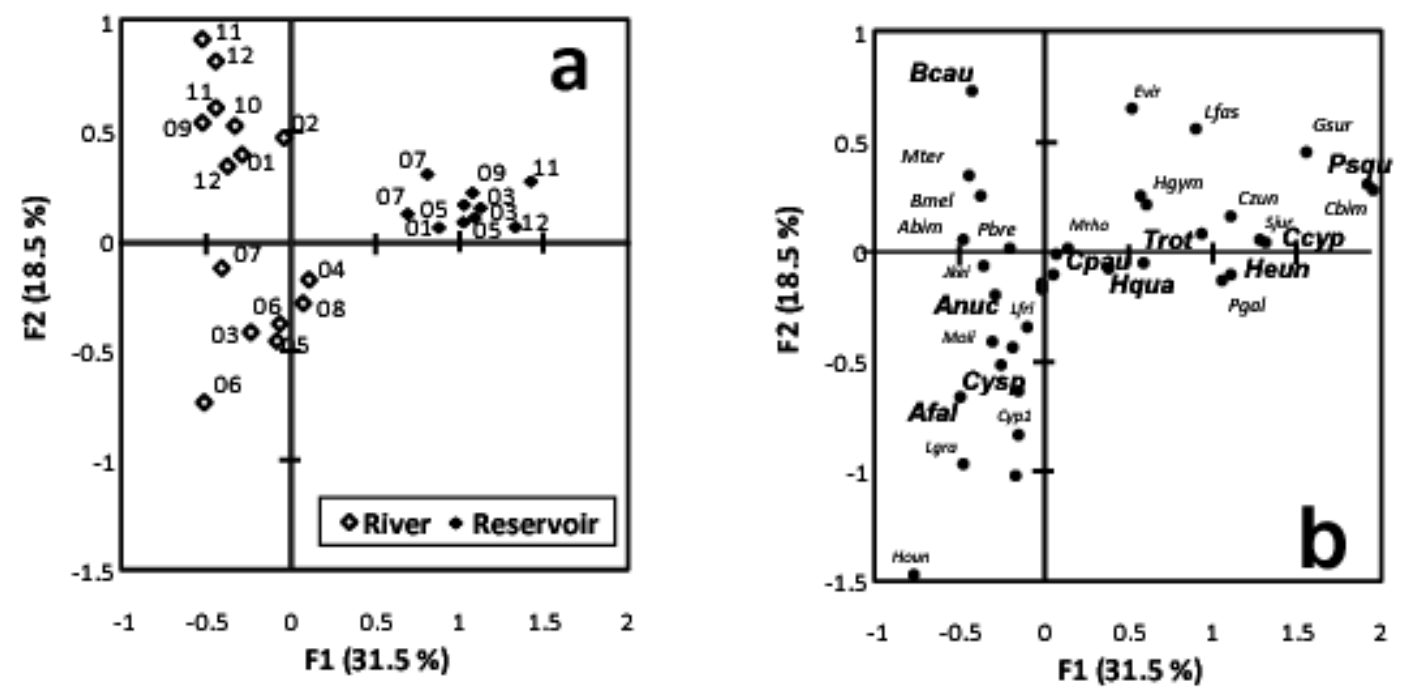

Fig. 3. Results of the principal correspondence analysis (PCA) on the species $\times$ capture matrix. a: plot of samples. The numbers indicate month of sampling. b: plot of the species. Bold type indicates the species whose contribution to axis 1 is higher than $1 \%$. The code species are explained in Table 1.

The mean of each trait in each sample was computed by multiplying the value of the trait for each species with the capture of the species in the sample, summing the result for all the species in the sample and dividing by the total number of fish captured. The resulting "sample $\times$ trait" matrix was treated by Principal Component Analysis in order to visualize the association between traits and samples. This association was tested by a non parametric ANOSIM test (Clarke and Warwick 2001), which consists of calculating an index (the global R) based on the comparison of rank similarities among replicates within and between sites. This index varies between 0 (no difference between sites) and 1 (no similarity between sites is greater than any similarity within sites). The value of this index is then recalculated under 999 permutations of the sample labels. The significance level of the difference between sites is given by the proportion of simulated values equal or larger than the observed value.

The contribution of each trait to the difference between samples was computed by the SIMPER procedure (Clarke and Gorley 2001; Clarke and Warwick 2001).

Correspondence analyses and Principal Component analyses were conducted using XLSTAT (Addinsoft ${ }^{\mathrm{TM}}$ ).

\section{Results}

\subsection{Changes in fish assemblages}

We captured 54 species in the river but only 39 in the reservoir (Table 3). Five species captured in the reservoir were absent from the samples captured in the river.

Among the species absent from the reservoir samples, three were regularly present in the river (Acestrorhynchus falcatus, Cyphocharax helleri and Anostomus brevior) but most of these were rare in the river samples. Conversely, some species were much more abundant in the reservoir than in the river. This was the case of Plagioscion squamosissimus; four Cichlid species: Cichlasoma bimaculatum, Geophagus surinamensis, Crenicichla saxatilis and Satanoperca jurupari; and one species belonging to the Sternopygidae: Eigenmannia virescens.

Thirty seven species each represented more than $0.1 \%$ of total capture in the river or reservoir samples. Together, these made up more than $99.5 \%$ of the capture and were retained in the statistical analyses.

The first axis of the correspondence analysis extracted $31.5 \%$ of the total variability in the samples and clearly separated the river assemblages from those of the reservoir (Fig. 3a). The second axis (18.5\% of the variability) seemed to be related to hydrological conditions in the river at the time of sampling. In the negative part of this axis we find the samples taken during the flood period (mainly March to July), and at the other end, samples taken during the low water season (September to January).

The main significantly contributing species associated with the reservoir samples were Triportheus rotundatus, Curimata cyprinoides, Hemiodus unimaculatus, Hemiodopsis quadrimaculatus, Plagioscion squamosissimus and Charax pauciradiatus, whereas Bryconops caudomaculatus, Auchenipterus nuchalis, Acestrorhynchus falcatus and Cyphocharax spilurus contributed significantly to the river samples (Fig. 3b).

PCA revealed good associations between traits and the spatial positions where samples were taken (Figs. $4 a-c)$. In the cases food, reproductive and morphological traits, factor 1 of the analysis extracted more than $50 \%$ of the total variability of the matrix and was related to the difference between river and reservoir samples. The differences were always highly significant $(p<0.001, p=0.002$ and $p<0.001$ for feeding, reproductive and locomotion traits, respectively). 

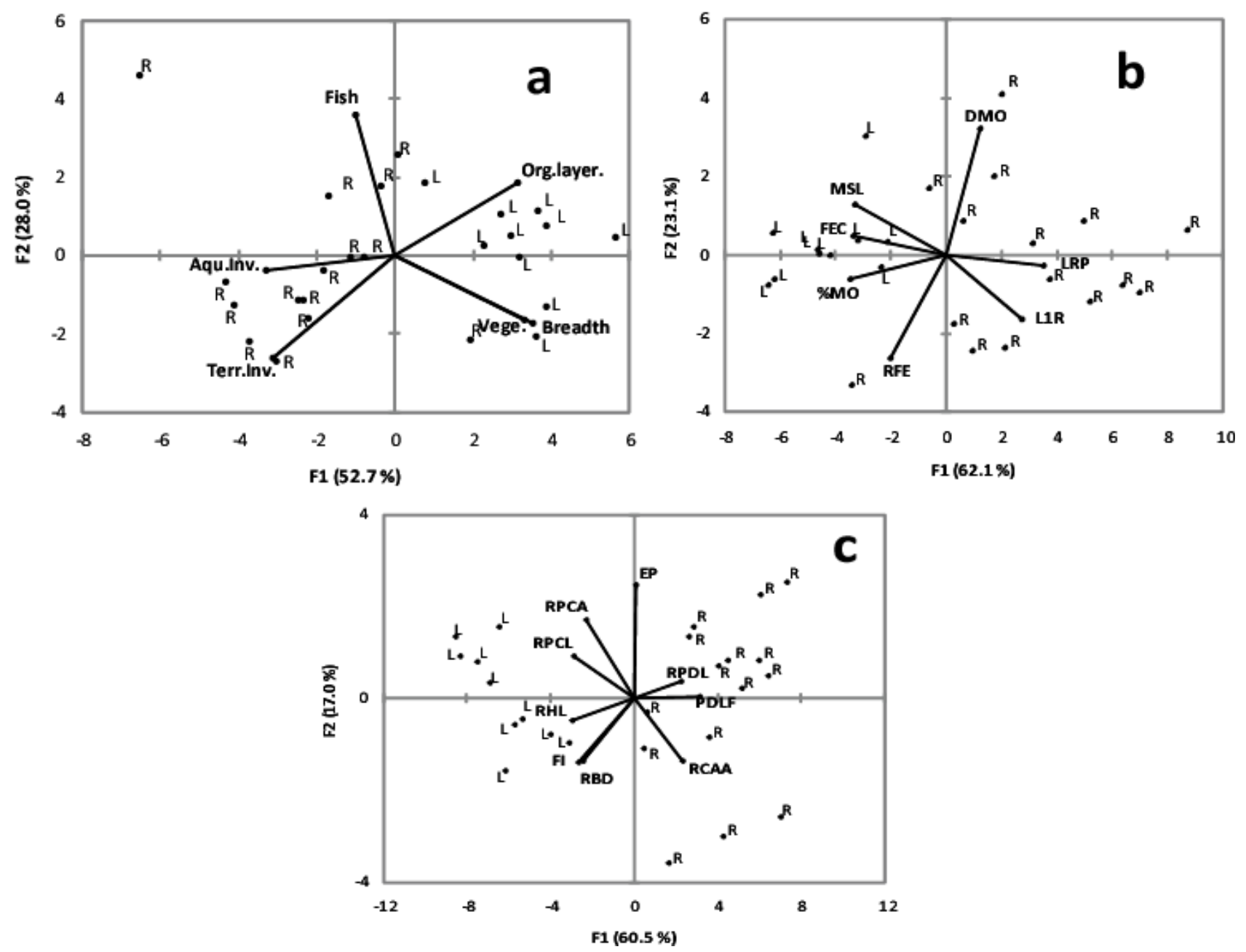

Fig. 4. Results of the principal component analyses (PCA) on the sample $\times$ ecological trait matrix. a: food items; $\mathbf{b}$ : reproductive traits; $\mathbf{c}$ : morphological traits. R: river; L: reservoir. See material and methods section for definitions of the abbreviations.

The food types associated with the river samples were terrestrial invertebrates and fish were, whereas organic benthic layer and vegetation were characteristic of the reservoir samples (Table 4); these four dietary components accounted for more than $98 \%$ of the difference between sites.

The reproductive traits that contributed the most to the differences in sample composition were fecundity and maximum observed length, which were higher in the reservoir samples (Table 4). River samples were characterised by late maturation, a long reproduction period and larger eggs, although these contributed little to the difference between sites.

As for morphological features, river samples were characterized by a long and deep caudal peduncle and large caudal fin, whereas a deep body, long head and long pectoral fin were more frequent in the reservoir samples.

\section{Discussion}

As there were positively no introductions into the Petit-Saut reservoir, those species present in the reservoir samples but absent in river samples had to have been present before the damming. Therefore, it is likely that the number of species lost was higher than the 15 revealed by these capture experiments.

Seven to eight years after the closure of Petit-Saut Dam, fish assemblages in the reservoir can be expected to be relatively stable. According to Agostinho et al. (1999) and based on past experiences (Gido and Matthews 2000), the time needed to achieve a state of equilibrium in tropical reservoirs is probably less than 10 years. After this time, numerous previous data show a decrease in fish species diversity in tropical reservoirs compared with their rivers (Reynolds 1990; Santos 1995; Chookajorn et al. 1999; Pholprasith and Sirimongkonthaworn 1999).

Despite the differences between the two environments sampled (river and reservoir), we considered the samples to be roughly comparable because we sampled similar habitats in each, using the same method. Absence of a species from a sample cannot be equated with its absence from the environment and the overall interpretation must mainly consider the difference in the relative abundance of species. 
Table 4. Results of the SIMPER analyses: contributions of (A) food items, (B) reproductive traits and (C) morphological traits to the difference in assemblages between river and reservoir.

\begin{tabular}{|c|c|c|c|c|c|c|c|}
\hline \multirow{2}{*}{\multicolumn{2}{|c|}{ Food item }} & & \multicolumn{5}{|c|}{ A. Contribution of food items } \\
\hline & & & $\begin{array}{c}\text { River } \\
\text { Mean \% }\end{array}$ & $\begin{array}{l}\text { Reservoir } \\
\text { Mean \% }\end{array}$ & \multirow{2}{*}{$\begin{array}{c}\text { Average } \\
\text { Dissimilarity }\end{array}$} & \multirow{2}{*}{$\begin{array}{c}\begin{array}{c}\text { Contribution } \\
\%\end{array} \\
39.13\end{array}$} & \multirow{2}{*}{$\begin{array}{c}\begin{array}{c}\text { Cumulative } \\
\text { Contrib. \% }\end{array} \\
39.13\end{array}$} \\
\hline Terrestrial invertebrates & & Terr Inv & 49.99 & 27.78 & & & \\
\hline Organic layer (detritus) & & Org. layer & 8.46 & 22.75 & 7.73 & 27.07 & 66.20 \\
\hline Fragments of plants & & Vege & 23.86 & 33.51 & 5.06 & 17.70 & 83.90 \\
\hline Fish & & Fish & 15.21 & 14.19 & 4.15 & 14.54 & 98.44 \\
\hline Aquatic invertebrates (ex & ecapoda) & Aqu Inv & 2.24 & 1.42 & 0.44 & 1.53 & 99.97 \\
\hline Feeding niche breadth & & Breadth & 0.08 & 0.10 & 0.01 & 0.03 & 100.00 \\
\hline \multirow{2}{*}{\multicolumn{2}{|c|}{ Reproductive trait }} & & \multicolumn{5}{|c|}{ B. Contribution of reproductive traits } \\
\hline & & & $\begin{array}{c}\text { River } \\
\text { Average }\end{array}$ & $\begin{array}{c}\text { Reservoir } \\
\text { Average }\end{array}$ & $\begin{array}{c}\text { Average } \\
\text { Dissimilarity }\end{array}$ & $\begin{array}{c}\text { Contribution } \\
\%\end{array}$ & $\begin{array}{l}\text { Cumulative } \\
\text { Contrib. \% }\end{array}$ \\
\hline Absolute fecundity & & FEC & 13884.98 & 23969.37 & 0.96 & 49.20 & 49.20 \\
\hline Max. Standard length & & MSL & 188.55 & 269.69 & 0.26 & 15.96 & 65.16 \\
\hline Relative fecundity & & RFE & 134.49 & 140.20 & 0.26 & 15.65 & 80.81 \\
\hline$\%$ Mature oocytes & & MO & 76.71 & 79.73 & 0.16 & 9.85 & 90.66 \\
\hline Relative length at first ma & & L1R & 52.94 & 50.16 & 0.12 & 7.66 & 98.33 \\
\hline Length of the reproductiv & & LRP & 10.11 & 8.88 & 0.03 & 1.55 & 99.87 \\
\hline Mean diameter of mature & & MDO & 0.91 & 0.86 & 0.00 & 0.13 & 100.00 \\
\hline \multirow{2}{*}{\multicolumn{2}{|c|}{ Morphological traits }} & \multicolumn{6}{|c|}{ C. Contribution of morphological traits } \\
\hline & & $\begin{array}{c}\text { River } \\
\text { Average }\end{array}$ & $\begin{array}{l}\text { Res } \\
\text { Av }\end{array}$ & & $\begin{array}{c}\text { Average } \\
\text { Dissimilarity }\end{array}$ & $\begin{array}{c}\text { Contribution } \\
\%\end{array}$ & $\begin{array}{l}\text { Cumulative } \\
\text { Contrib. } \%\end{array}$ \\
\hline Peduncle flatness & PDLF & 4.41 & & & 4.17 & 48.34 & 48.34 \\
\hline Flatness index & FI & 2.34 & & & 3.02 & 36.06 & 83.40 \\
\hline Relative (R.) body depth & RBD & 0.27 & & & 0.34 & 4.00 & 87.41 \\
\hline R. Pectoral length & RPCL & 0.18 & & & 0.30 & 3.49 & 90.89 \\
\hline R. Head length & RHL & 0.23 & & & 0.27 & 3.19 & 94.08 \\
\hline Eye position & $\mathrm{EP}$ & 0.47 & & & 0.26 & 2.97 & 97.05 \\
\hline R. Pectoral fin area & RPCA & 0.07 & & & 0.11 & 1.27 & 98.32 \\
\hline R. Caudal fin area & RCAA & 0.24 & & & 0.10 & 1.15 & 99.47 \\
\hline R. Peduncle length & RPDL & 0.12 & & & 0.05 & 0.53 & 100.00 \\
\hline
\end{tabular}

Some species showed a profound decrease in their abundance or even a complete disappearance from the reservoir samples compared with the river ones; as was the case of Acestrorhynchus falcatus, a medium-sized piscivore and Cyphocharax helleri, a small detritivore. The river contains some close congeneric species and it can be hypothesized that a decrease in the number of niches in the reservoir compared with the river could have prevented the co-existence of these pairs of species (Agostinho et al. 2003). This hypothesis is compatible with the findings of Mason et al. (2008), who showed that lake fish communities are driven by niche complementarity processes.

The changes in relative abundances of species between the fish assemblages from the Sinnamary River and Petit-Saut Reservoir were shown to be linked to the ecological strategies of the fish species. The formation of the reservoir led to drastic changes in fish habitat. Such transformations effectively "filtered" the riverine fish species, preventing colonization by those that could not find suitable living conditions in the manmade lake and could not adapt themselves.

\subsection{Feeding strategies}

The first pressure imposed on fish when there is a radical transformation of their environment, is food related. Individual fish must first succeed in obtaining enough energy to maintain their basic metabolism and then to reproduce. In the Sinnamary River, external supplies constitute a large part of the food resources used by the fish (Horeau et al. 1996), whereas plankton, algae and aquatic invertebrates are only present in small quantities (Mérona et al. 2003). After an initial supply of large 
quantities of allochtonous material generated by the decomposition of vegetation and litter during the reservoir filling and subsequent stabilization, these resources become scarce and autochtonous resources like detritus, algae, periphyton and aquatic invertebrates, predominate (Mérona et al. 2003). It is then expected that the species adapted to allochtonous resources, like terrestrial insects, in the river would have difficulty colonizing the reservoir. Conversely, species feeding on the organic layer developing on substrates should be favoured during the process of reservoir colonization. The relative importance of species feeding on autochtonous food has been pointed out in all previous studies on reservoir fish communities (Araujo Lima et al. 1995; Agostinho et al. 2007). From an analysis of the trophic structure of fish assemblages in 77 reservoirs in Brasil, Agostinho et al. (2007) determined that omnivores, piscivores, detritivores and herbivores are the dominant species in reservoirs. In Petit-Saut Reservoir, the average percentage of detritus and vegetation suggested that detritivores and herbivores should be more abundant than in the river. Conversely, our data did not confirm the prevalence of piscivores in the reservoir. This disagreement is probably due to differences in the specific composition of river ichthyofauna prior to damming, as suggested by Agostinho et al. (1999). In the Sinnamary River, unlike in the other main dammed South America rivers, there are few (actually only one) large piscivorous species. Compared with a previous study addressing the first years of the Petit-Saut Reservoir, the patterns observed here show a drastic transformation of trophic structure (Mérona 2005). Soon after the flooding of the lake, a large number of terrestrial insects became available from the dying submerged trees and the invertivores feeding on this resource were abundant in the reservoir. As time went on, however, this ephemeral resource ran out and these fish species were no longer able to persist in the man-made lake. Thus, in a state of dynamic equilibrium, the "filter" for terrestrial insect feeders in large reservoirs seems to be a general pattern.

\subsection{Reproductive strategies}

Having fulfilled their nutritional requirements, species must reproduce in order to persist in the transformed environment. The change in hydrological variability, a parameter known to significantly affect the representation of mean life history traits in fish communities (Tedesco et al. 2008), was one of the most prominent transformations in the Petit-Saut Reservoir after its filling. Fish in the Sinnamary River before damning experienced large stochastic variations in discharge and water level and, as a consequence, opportunistic/periodic strategies dominated the community (Ponton and Mérona 1998). Conversely, the hydrological regime in Petit-Saut Reservoir is much more regular, with a constant periodicity of high and low water (Fig. 2). Under these conditions, our data show that a large maximum length, high fecundity, short reproductive period and single bout per year were the life-history traits of riverine species that favoured their colonization of the reservoir's pelagic compartment. These traits are compatible with the periodic strategy according to Winemiller's classification
(Winemiller 1989, 1992). Data on the life-history strategies of fish species in reservoirs are sparse in the literature (Agostinho et al. 2007; Mérona et al. 2010). Some information exists on individual species but not at the community level, a fact that prevents statistical analyses on the relation between species traits and community composition (Mérona et al. 2009). Based on the specific composition of fish communities in the literature, it appears that reservoirs house a large number of species that exhibit low fecundity combined with some sort of parental care, an observation that seems contradictory with our results (Balon 1973; Latif and Rashid 1973; Rashid 1995; Agostinho et al. 2007). However, most of these species avoid the pelagic compartment, and concentrate in the shallow marginal areas that were not taken into account by our sampling (Balogun and Ibeun 1995; Machena 1995).

\subsection{Swimming strategies}

Our results on the morphological features related to the capacity to colonize the reservoir are compatible with some previous detailed studies (Gatz 1979a,b; Sfakiotakis et al. 1999; Gillespie and Fox 2003). The morphological traits favoured in the reservoir were long and large pectoral fins, a long head and a deep body, whereas fish in the river tended to have large caudal fins and long caudal peduncles. These morphological features associated with the reservoir assemblages are obviously related to the swimming ability of the fish. According to Gatz (1979a), relative body depth is assumed to be inversely related to habitat water velocity and directly related to capacity for making vertical turns. Also, relative length of the pectoral fins is related to low speed manoeuvring characteristics of fish living in quiet water, and relative area of pectoral fins is directly proportional to the braking capacity of the fin, fanning to maintain position, and to capacity for acceleration from a stationary position. Associated with the river assemblages, relative peduncle length and relative caudal fin area are also traits closely related to swimming ability, characteristic of fish living in strong currents, where the peduncle-caudal fin system acts as an efficient propelling device (Sfakiotakis et al. 1999). Relative head length, associated with reservoir assemblages, is related to prey size, meaning that fish with a long head would present a large ratio of length of prey/length of predator, a characteristic that optimizes the efficiency of foraging. This was the case of the three species of Cichlids (Cichlasoma bimaculatum, Geophagus surnamensis and Satanoperca jurupari), which present the highest relative head length in our data.

The last morphological trait, the caudal peduncle flatness, is assumed to be inversely related to amplitude of swimming movements (Gatz 1979a) and was associated with the river assemblages. Fish in flowing water use up energy while resisting the current, and must develop energy-saving foraging strategies. In our data on the species associated with the river, Auchenipterus nuchalis and Hoplias malabaricus present high values of relative peduncle flatness. The former is a small pelagic species feeding preferentially on the terrestrial invertebrates falling from the riparian vegetation and the latter is a large 
piscivore hunting from a hide; neither of these two foraging strategies require much energy (Mérona et al. 2003). Morphological structure of communities in reservoirs has been seldom studied. In the Tucurui Reservoir (Brazil), (Mérona et al. 2010) demonstrated an increase in the abundance and number of fish species with deep bodies, large pectoral fins and eyes and mouths in median positions compared with the abundance of such species in the river before impoundment, a result which is compatible with the conclusions of the present study.

\section{Conclusion}

(1) composition and structure of the pelagic fish community, show large differences between the reservoir and the river of origin;

(2) feeding strategies of fish species appeared to be a good predictor of the type of riverine species most able to develop in the Petit-Saut reservoir;

(3) reproductive traits and morphology associated with swimming ability may be used as indicators to forecast the type of species which will proliferate in reservoirs.

These conclusions may not be applicable to every reservoir, as a number of factors could influence the colonization success of fish species from the river. These factors can be of external origin, such as dam operation schedule and fishing pressure, or of internal origin, such as the type of river dammed, the position of the reservoir in relation to the longitudinal profile and the interactions between competing species.

Acknowledgements. This work was funded by Electricité de France (EDF). The authors would like to thank the technical staff of Hydreco - Roland Aboïkoni, Laurent Guillemet, Benoit Burban, Sébastien Lereun and Simon Clavier - for their help with the field collections.

\section{References}

Agostinho A.A., Gomes L.C., Pelicice F.M., 2007, Ecologia e Manejo de recursos pesqueiros em Reservatorios do Brasil. Maringa, Brazil, Editora da Universidade Estadual de Maringa.

Agostinho A.A., Miranda L.E., Bini L.M., Gomes L.C., Thomaz S.M., Suzuki H.I., 1999, Patterns of colonization in neotropical reservoirs, and prognoses on aging. In: Tundisi J.G., Straskraba M. (Eds.), Theoretical reservoir ecology and its applications, International Institute of Ecology, Brazilian Academy of Sciences and Backhuys Publishers, pp. 227-265.

Agostinho C.S., Hahn N.S., Marques E.E., 2003, Patterns of food resource use by two congeneric species of piranhas (Serrasalmus) on the upper Parana River floodplain. Braz. J. Biol. 63, 177-182.

Araujo Lima C.A.R.M., Agostinho A.A., Fabre N.N., 1995, Trophic aspects of fish communities in Brazilian rivers and reservoirs. In: Tundisi J.G., Bicudo C.E.M., Matsamura Tundisi T. (Eds.), Limnology in Brazil. Brazil, Brazilian Academy of Sciences/ Brazilian Limnological Society, pp. 105-136.
Balogun J.K., Ibeun M.O., 1995, Additional information on fish stocks and fisheries of Lake Kainji (Nigeria). In: Crul R.C.M., Roest F.C. (Eds.), CIFA Techn. Pap. Rome, FAO, pp. 1-18.

Balon E.K., 1973, Results of fish population size assessments in Lake Kariba Coves (Zambia), a decade after their creation. In: Ackermann W.C., White G.F., Worthington E.B. (Eds.), ManMade Lakes: Their Problems and Environmental Effects. Washington, American Geophysical Union, pp. 149-158.

Charvet S., Statzner B., Usseglio-Polatera P., Dumont B., 2000, Traits of benthic macrionvertebrates in semi-natural French streams: an initial application to biomonitoring in Europe. Freshw. Biol. 43, 277-296.

Chookajorn T., Duangsawadi S., Cahnsawang B., Leenanond Y., Sricharoendham B., 1999, The fish populations in Rajjaprabha Reservoir, Thailand. In: van Densen W.L.T., Morris M.J. (Eds.), Fish and fisheries of lakes and reservoirs in Southeast Asia and Africa. Otley, UK, Westbury Publishing, pp. 95-102.

Clarke K.R., Gorley R.N., 2001, PRIMER v5: User Manual/Turorial. Plymouth, United Kingdom, PRIMER-E Ltd.

Clarke K.R., Warwick R.M., Eds. 2001, Change in marine communities. An approach to statistical analysis and interpretation., Plymouth, UK, PRIMER-E Ltd.

Gatz A.J., 1979a, Ecological morphology of freshwater stream fishes. Tulane Stud. Zool. Botany 21, 91-124.

Gatz A.J., 1979b, Community organization in fishes as indicated by morphological features. Ecology 60, 711-718.

Gido K.B., Matthews W.J., 2000, Dynamics of the offshore fish assemblage in a Southwestern Reservoir (Lake Texoma, Oklahoma-Texas). Copeia 4, 917-930.

Gillespie G.J., Fox M.G., 2003, Morphological and life-history differentiation between littoral and pelagic forms of pumpkinseed. J. Fish Biol. 62, 1099-1115.

Hoeinghaus D.J., Winemiller K.O., Birnbaum J.S., 2007, Local and regional determinants of stream fish assemblage structure: inferences based on taxonomic vs. functional groups. J. Biogeogr. 34, 324-338.

Horeau V., Cerdan P., Champeau A., Richard S., 1996, Importance des apports exogènes dans le régime alimentaire de quelques poissons de "criques" du bassin versant du fleuve Sinnamary (Guyane française). Rev. Ecol. (Terre et Vie) 51, 29-41.

Hurlbert S.H., 1978, The measurement of niche overlap and some relatives. Ecology 59, 67-77.

Ita E.O., 1984, Kainji (Nigeria). In: Kapetsky J.M., Petr T. (Eds.), Status of African reservoir fisheries/ Etat des pêcheries dans les réservoirs d'Afrique. Rome, FAO, pp. 43-104.

Karr J.R., 1981, Assessment of biotic integrity using fish communities. Fisheries 6, 21-27.

Keith P., Le Bail P.-Y., Planquette P., Eds. 2000, Atlas des poissons d'eau douce de Guyane. Tome 2, Fasc. I. Paris, MNHN/SPN.

Latif A.F.A., Rashid M.M., 1973, Catch of fishes from Lake Nasser, Egypt, in the early years of impoundment, 1966-1969. In: Ackermann W.C., White G.F., Worthington E.B. (Eds.), ManMade Lakes: their problems and environmental effects. Washington, American Geophysical Union, pp. 661-663.

Le Bail P.-Y., Keith P., Planquette P., Eds. 2000, Atlas des poissons d'eau douce de Guyane. Tome 2, Fasc. II. Paris, MNHN/SPN.

Lelek A., El Zarka S., 1973, Ecological comparison of the preimpoundment and postimpoundment fish faunas of the River 
Niger and Kainji Lake, Nigeria. In: Ackermann W.C., White G.F., Worthington E.B. (Eds.), Man-Made Lakes: Their Problems and Environmental Effects. Washington, American Geophysical Union, pp. 655-660.

Machena D., 1995, Recent developments in the fisheries of Lake Kariba (Zambia/Zimbabwe). In: Crul R.C.M., Roest F.C. (Eds.), CIFA Technical Paper. Rome, FAO, pp. 41-80.

Mason N.W.H., Lanoiselée C., Mouillot D., Wilson J.B., Argillier C., 2008, Does niche overlap control relative abundance in French lacustrine fish communities? A new method incorporating functional traits. J. Anim. Ecol. 77, 661-669.

Mérona B.de, 2005, Le fleuve, le barrage et les poissons. Montpellier, IRD.

Mérona B.de, Albert P., 1999, Ecological monitoring of fish assemblages downstream of a hydroelectric dam in French Guiana (South America). Regul. Rivers Res. Manage. 15, 339-351.

Mérona B.de, Juras A.A., Santos G.M.D., Cintra I.H.A., 2010, Os peixes e a pesca no Baixo rio Tocantins, vinte anos depois da UHE Tucurui. Brasilia, Eletronorte.

Mérona B.de, Mol J.H., Vigouroux R., Chaves P.de T., 2009, Phenotypic plasticity in fish life-history traits in two neotropical reservoirs: Petit-Saut Reservoir in French Guiana and Brokopondo Reservoir in Suriname. Neotrop. Ichthyol. 7, 683-692.

Mérona B.de, Vigouroux R., Horeau V., 2003, Changes in the food resources and their utilization by fish assemblages in a large tropical reservoir in South America (Petit-Saut dam, French Guiana). Acta Oecol. 24, 147-156.

Mol J.H., Mérona B.de, Ouboter P.E., Sahdew S., 2007, The fish fauna of Brokopondo Reservoir, Suriname during 40 years of impoundment. Neotrop. Ichthyol. 5, 351-368.

Pholprasith S., Sirimongkonthaworn R., 1999, The fish community of Ubolratana Reservoir, Thailand. In: van Densen W.L.T., Morris M.J. (Eds.), Fish and fisheries of lakes and reservoirs in Southeast Asia and Africa. Otley, UK, Westbury Publishing, pp. 103-115.

Planquette P., Keith P., Le Bail P.-Y., (Dir.), 1996, Atlas des Poissons d'eau douce de Guyane. Ttome 1. Paris, IEGB - MNHN, INRA, CSP, Minist. Environnement.

Ponton D., Mérona B.de, 1998, Fish Life-history tactics in a neatropical river with a highly stochastic hydrological regime: the Sinnamary River, French Guiana, South America. Pol. Arch. Hydrobiol. 45, 201-224.

Rashid M.M., 1995, Some additional information on the limnology and fisheries of Lakes nasseer (Egypt) and Nubia (Sudan).
In: Crul R.C.M., Roest F.C. (Eds.), CIFA Techn. Pap. Rome, FAO, pp. 81-110.

Reynolds J.D., 1990, A guide to the external sexing of some West African Freshwater fishes. Ghana J. Sci. 11, 3-10.

Santos G.M.dos, 1995, Impactos da hidrelétrica Samuel sobre as communidades de peixes do Rio Jamari (Rondônia, Brasil). Acta Amazonica 25, 247-280.

Santos G.M.dos, Mérona B.de, 1996, Impactos imediatos da UHE Tucurui sobre as communidades de peixes e a pesca. In: Magalhaes S.B., Britto R.D.C., Castro E.R.D. (Eds.), Energia na Amazônia Belem, PA, Brasil, Museu Paraense Emilio Goeldi, UFPA, Assoc. Univ. Amazônicos, pp. 251-258.

Sfakiotakis M., Lane D.M., Davies J.B.C., 1999, Review of fish swimming modes for aquatic locomotion. IEEE J. Oceanic Eng. 24, 237-252.

Sissakian C., 1997, Présentation générale de l'aménagement hydroélectrique de Petit-Saut (Guyane française) et du programme de suivi élcologique lié à sa mise en eau. Hydroecol. Appl. 9, 1-22.

Southwood T.R.E., 1977, Habitat, the templet for ecological strategies? J. Anim. Ecol. 46, 337-365.

Tedesco P.A., Hugueny B., Oberdorff T., Dürr H.H., Mérigoux S., Mérona B.de, 2008, River hydrological seasonality influences life history strategies of tropical riverine fishes. Oecologia 156, 691702.

Tonn W.M., Magnuson J.J., Rask M., Toivonen J., 1990, Intercontinental comparison of small-lake fish assemblages: the balance between local and regional processes. Am. Nat. 136, 345-375.

Townsend C.R., Doledec S., Scarsbrook M.R., 1997, Species traits in relation to temporal and spatial heterogeneity in streams : a test of habitat templet theory. Freshw. Biol. 37, 367-387.

Townsend C.R., Hildrew A.G., 1994, Species traits in relation to a habitat templet for river systems. Freshw. Biol. 31, 265-275.

Vanderpuye C.J., 1984, Volta Lake (Ghana). In: Kapetsky J.M., Petr T. (Eds.), CIFA Technical Paper. Rome, FAO, pp. 261-319.

Winemiller K.O., 1989, Patterns of variation in life history among South American fishes in seasonal environments. Oecologia 81, 225-241.

Winemiller K.O., 1992, Life-history strategies and the effectiveness of sexual selection. Oikos 63, 318-327.

Winemiller K.O., Rose K.A., 1992, Patterns of life-history diversification in North American fishes: implications for population regulation. Can. J. Fish. Aquat. Sci. 49, 2196-2218. 
Appendix 1. Life-history traits of 39 fish species in the Sinnamary River. MSL: maximum standard length; LRP: length of reproductive period; L1R: relative length at first maturity; FEC: absolute fecundity; RFE: relative fecundity; MO: percentage of mature oocytes in the ovary; MDO: mean diameter of mature oocytes. List of species codes in Table 1.

\begin{tabular}{|c|c|c|c|c|c|c|c|}
\hline \multirow[t]{2}{*}{ Species Code } & \multirow{2}{*}{$\begin{array}{l}\text { Size } \\
\text { MSL } \\
(\mathrm{mm})\end{array}$} & \multirow{2}{*}{$\begin{array}{c}\text { Reproductive period } \\
\text { LRP } \\
\text { (month) }\end{array}$} & \multirow{2}{*}{$\begin{array}{c}\text { Length at first } \\
\text { maturity }\end{array}$} & \multicolumn{2}{|c|}{ Fecundity } & \multirow{2}{*}{$\begin{array}{c}\text { Mature } \\
\text { Oocyte }\end{array}$} & \multirow{2}{*}{$\begin{array}{l}\text { Oocyte Diameter } \\
\text { MDO } \\
(\mathrm{mm})\end{array}$} \\
\hline & & & & $\begin{array}{c}\text { FEC } \\
\text { (number) }\end{array}$ & $\begin{array}{c}\text { RFE } \\
(\mathrm{nb} / \mathrm{g})\end{array}$ & & \\
\hline Abim & 173 & 6 & 48 & 25398 & 390 & 88 & 0.7 \\
\hline Abre & 123 & 4 & 58 & 307 & 32 & 44 & 0.9 \\
\hline Afal & 287 & 12 & 53 & 16459 & 124 & 84 & 0.8 \\
\hline Amic & 271 & 8 & 47 & 2475 & 66 & 74 & 0.7 \\
\hline Anuc & 145 & 11 & 43 & 687 & 28 & 69 & 1.4 \\
\hline Baff & 127 & 10 & 69 & 851 & 56 & 83 & 0.7 \\
\hline Bcau & 128 & 11 & 62 & 3082 & 138 & 75 & 0.7 \\
\hline Bmel & 143 & 12 & 66 & 1770 & 92 & 83 & 0.7 \\
\hline Cbim & 150 & 2 & 67 & 2066 & 49 & 99 & 1.2 \\
\hline Ccyp & 258 & 9 & 40 & 43325 & 249 & 84 & 0.6 \\
\hline Chel & 117 & 4 & 69 & 41768 & 898 & 87 & 0.6 \\
\hline Cpau & 150 & 10 & 59 & 3605 & 107 & 80 & 0.7 \\
\hline Cyp1 & 134 & 4 & 60 & 24540 & 802 & 97 & 0.5 \\
\hline Cysp & 152 & 6 & 50 & 22084 & 492 & 93 & 0.5 \\
\hline Czun & 96 & 10 & 78 & 1560 & 81 & 75 & 1.3 \\
\hline Evir & 298 & 2 & 34 & 819 & 41 & 84 & 1.4 \\
\hline Gsur & 156 & 2 & 87 & 324 & 7 & 63 & 2.2 \\
\hline Haim & 830 & 12 & 55 & 72868 & 13 & 91 & 2.1 \\
\hline Heun & 240 & 6 & 83 & 547836 & 265 & 92 & 0.7 \\
\hline Hgym & 196 & 8 & 49 & 185 & 3 & 64 & 4.8 \\
\hline Hmal & 334 & 12 & 48 & 5813 & 14 & 63 & 1.3 \\
\hline Houn & 250 & 2 & 85 & 43748 & 128 & 88 & 1.2 \\
\hline Hqua & 200 & 12 & 46 & 8748 & 142 & 67 & 0.8 \\
\hline Jkei & 105 & 12 & 59 & 5845 & 457 & 95 & 0.7 \\
\hline Jmeu & 115 & 6 & 57 & 4521 & 299 & 86 & 0.7 \\
\hline Lfas & 382 & 8 & 39 & 78557 & 143 & 94 & 0.9 \\
\hline Lfri & 405 & 8 & 40 & 159627 & 146 & 77 & 0.9 \\
\hline Lgos & 253 & 6 & 60 & 37822 & 210 & 89 & 1.2 \\
\hline Lgra & 245 & 6 & 54 & 11862 & 84 & 87 & 1.5 \\
\hline Mgeo & 113 & 4 & 59 & 3440 & 260 & 84 & 0.7 \\
\hline Moli & 100 & 10 & 70 & 11130 & 513 & 91 & 0.6 \\
\hline Mrho & 390 & 4 & 63 & 1512 & 2 & 47 & 1.2 \\
\hline Msur & 116 & 4 & 78 & 8412 & 276 & 95 & 0.7 \\
\hline Mter & 247 & 6 & 67 & 6528 & 14 & 69 & 2.1 \\
\hline Pbre & 126 & 12 & 54 & 2507 & 104 & 69 & 0.7 \\
\hline Pgal & 238 & 8 & 57 & 2036 & 21 & 61 & 1.4 \\
\hline Psqu & 595 & 3 & 74 & 13665 & 5.8 & 73 & 0.6 \\
\hline Sjur & 158 & 2 & 58 & 389 & 7 & 90 & 2.0 \\
\hline Trot & 381 & 8 & 45 & 26018 & 118 & 83 & 0.9 \\
\hline
\end{tabular}


Appendix 2. Mean morphological parameters of 39 fish species in the Sinnamary River. RHL: relative head length, FI: flatness index, RBD: relative body depth, RPDL: relative peduncule length, PDLF: peduncule flatness, RCCA: relative caudal fin area, RPCL: relative pectoral length, RPCA: relative pectoral area, EP: eye position. See methods for parameter definitions. List of species codes in Table 1.

\begin{tabular}{|c|c|c|c|c|c|c|c|c|c|c|}
\hline Species Code & $\mathrm{Nb}$ & RHL & FI & RBD & RPDL & PDLF & RCAA & RPCL & RPCA & EP \\
\hline Abim & 9 & 0.23 & 3.11 & 0.43 & 0.13 & 4.42 & 0.17 & 0.20 & 0.06 & 0.50 \\
\hline Abre & 8 & 0.26 & 2.15 & 0.26 & 0.11 & 4.35 & 0.26 & 0.15 & 0.08 & 0.17 \\
\hline Afal & 10 & 0.29 & 2.23 & 0.20 & 0.07 & 2.85 & 0.26 & 0.15 & 0.07 & 0.61 \\
\hline Amic & 9 & 0.28 & 2.09 & 0.18 & 0.08 & 2.29 & 0.29 & 0.14 & 0.05 & 0.63 \\
\hline Anuc & 7 & 0.18 & 1.80 & 0.18 & 0.12 & 6.18 & 0.23 & 0.14 & 0.07 & 0.32 \\
\hline Baff & 6 & 0.22 & 2.07 & 0.27 & 0.13 & 3.86 & 0.23 & 0.17 & 0.09 & 0.60 \\
\hline Bcau & 10 & 0.22 & 2.08 & 0.26 & 0.13 & 4.03 & 0.25 & 0.19 & 0.09 & 0.56 \\
\hline Bmel & 9 & 0.23 & 2.12 & 0.26 & 0.13 & 4.06 & 0.22 & 0.20 & 0.11 & 0.58 \\
\hline Cbim & 1 & 0.35 & 2.04 & 0.46 & 0.13 & 2.91 & 0.21 & 0.34 & 0.17 & 0.52 \\
\hline Ссур & 4 & 0.30 & 2.66 & 0.39 & 0.14 & 3.86 & 0.25 & 0.19 & 0.06 & 0.27 \\
\hline Chel & 6 & 0.26 & 2.14 & 0.34 & 0.14 & 5.08 & 0.28 & 0.19 & 0.06 & 0.26 \\
\hline Cpau & 7 & 0.27 & 3.80 & 0.37 & 0.07 & 3.52 & 0.18 & 0.21 & 0.05 & 0.56 \\
\hline Cyp1 & 1 & 0.25 & 2.02 & 0.35 & 0.11 & 4.56 & 0.22 & 0.19 & 0.18 & 0.32 \\
\hline Cysp & 7 & 0.22 & 2.50 & 0.32 & 0.12 & 3.88 & 0.31 & 0.16 & 0.04 & 0.29 \\
\hline Czun & 2 & 0.28 & 2.70 & 0.34 & 0.12 & 3.16 & 0.30 & 0.17 & 0.10 & 0.33 \\
\hline Evir & 7 & 0.12 & 2.40 & 0.13 & 0.00 & 0.00 & 0.00 & 0.08 & 0.06 & 0.48 \\
\hline Gsur & 6 & 0.32 & 2.80 & 0.40 & 0.15 & 3.97 & 0.29 & 0.32 & 0.08 & 0.44 \\
\hline Haim & 10 & 0.33 & 1.52 & 0.21 & 0.14 & 7.58 & 0.33 & 0.15 & 0.08 & 0.58 \\
\hline Heun & 1 & 0.24 & 1.85 & 0.25 & 0.15 & 1.87 & 0.28 & 0.15 & 0.18 & 0.56 \\
\hline Hgym & 7 & 0.31 & 0.76 & 0.18 & 0.01 & 3.12 & 0.52 & 0.25 & 0.28 & 0.55 \\
\hline Hmal & 11 & 0.32 & 1.88 & 0.22 & 0.14 & 5.57 & 0.35 & 0.13 & 0.06 & 0.60 \\
\hline Houn & 1 & 0.30 & 1.30 & 0.22 & 0.11 & 2.83 & 0.36 & 0.15 & 0.21 & 0.43 \\
\hline Hqua & 7 & 0.25 & 2.08 & 0.25 & 0.12 & 3.05 & 0.41 & 0.15 & 0.13 & 0.54 \\
\hline Jkei & 12 & 0.27 & 3.78 & 0.44 & 0.12 & 3.62 & 0.26 & 0.20 & 0.07 & 0.52 \\
\hline Jmeu & 12 & 0.27 & 3.43 & 0.42 & 0.10 & 4.09 & 0.23 & 0.21 & 0.06 & 0.53 \\
\hline Lfas & 4 & 0.26 & 1.75 & 0.27 & 0.10 & 3.77 & 0.26 & 0.17 & 0.06 & 0.37 \\
\hline Lfri & 7 & 0.26 & 1.95 & 0.30 & 0.12 & 3.71 & 0.29 & 0.16 & 0.07 & 0.24 \\
\hline Lgos & 7 & 0.26 & 1.90 & 0.30 & 0.12 & 2.53 & 0.29 & 0.16 & 0.09 & 0.23 \\
\hline Lgra & 10 & 0.26 & 2.12 & 0.29 & 0.11 & 3.59 & 0.26 & 0.16 & 0.07 & 0.36 \\
\hline Mgeo & 1 & 0.27 & 2.43 & 0.43 & 0.09 & 2.20 & 0.11 & 0.26 & 0.02 & 0.43 \\
\hline Moli & 10 & 0.27 & 2.67 & 0.38 & 0.11 & 3.79 & 0.24 & 0.20 & 0.05 & 0.55 \\
\hline Mrho & 1 & 0.29 & 4.71 & 0.66 & 0.07 & 3.06 & 0.26 & 0.20 & 0.12 & 0.48 \\
\hline Msur & 10 & 0.25 & 3.09 & 0.41 & 0.12 & 3.98 & 0.17 & 0.20 & 0.04 & 0.54 \\
\hline Mter & 7 & 0.26 & 4.52 & 0.61 & 0.11 & 3.88 & 0.19 & 0.18 & 0.05 & 0.35 \\
\hline Pbre & 10 & 0.25 & 4.63 & 0.54 & 0.09 & 3.13 & 0.19 & 0.22 & 0.04 & 0.54 \\
\hline Pgal & 1 & 0.21 & 1.49 & 0.30 & 0.07 & 4.05 & 0.27 & 0.19 & 0.12 & 0.30 \\
\hline Psqu & 1 & 0.32 & 1.64 & 0.29 & 0.04 & 2.09 & 0.16 & 0.21 & 0.05 & 0.38 \\
\hline Sjur & 6 & 0.34 & 2.06 & 0.36 & 0.14 & 3.71 & 0.24 & 0.30 & 0.12 & 0.58 \\
\hline Trot & 6 & 0.26 & 2.81 & 0.30 & 0.09 & 3.01 & 0.14 & 0.28 & 0.20 & 0.49 \\
\hline
\end{tabular}

